\title{
Cognitive-behavioral therapy and elderly
}

\section{Opinion}

In this short review, I will deal with aspects related to the elderly phase and the work of Cognitive-Behavioral Therapy. This issue is relevant since elderly refers to the phase that begins at 65 years of age. Due to the development of medicine, as well as the improvement in public policies and quality of life of the population, the number of elderly people is increasing. This allows the work of the geriatrician as well as of the psychologist to be of great value, since there are several physical and mental health needs of the elderly person. ${ }^{1}$

Cognitive-behavioral therapy (CBT) proposes that thoughts influence people's moods and behaviors. ${ }^{2}$ In this sense, the goal of CBT is to restructure distorted thoughts and develop solutions that allow changes and improvement of mental disorders or issues related to a certain phase of life.

Among the principles of CBT is the valorization of a strong therapeutic alliance, which emphasizes active collaboration between patient and therapist. In addition, it is oriented to current problems, since objectives are defined with which they will be handled during the process. Another important characteristic is the educational character of this therapy, which allows the patient to be taught by his own therapist, favoring a shorter duration of the process. ${ }^{2}$ In therapy with the elderly, work focused mainly on autonomy is important, a factor that may be compromised by cycle life's problems. ${ }^{3}$ Another characteristic to be worked out is the different types of loss, since it is a predominant theme, characteristic of the emotional experiences of the elderly. An elderly person must deal with many losses, changing status and professional prestige, and declining physical and health skills. This causes them to spend a great deal of emotional and physical energy in mourning, resolving it and adapting to change. As a consequence, a poorly adapted response to loss is depression.

Elderly therapy may occur individually as well as in a group setting. The group form has a differential since it will contribute to the process of strengthening ties and social interaction, since the maintenance of social activities has value for physical and emotional well-being. The sessions aim at exchanging common experiences and difficulties for the stage of life they are experiencing, which allows them to accept their status as elderly and to learn from other experiences that may be useful to them. ${ }^{3,4}$

The aging process is characterized by a gradual decline in the functioning of all body systems. In this sense, in the individual sessions, the most used strategies in CBT with the elderly refer to adaptations that minimize the effect of cognitive losses, such as the use of schedules, reminders, and the strengthening of already used
Volume 3 Issue I - 2018

\author{
Rafaela Fava de Quevedo \\ Specialist in Cognitive-Behavioral Therapy, University of Caxias \\ do Sul, Brazil
}

Correspondence: Rafaela Fava de Quevedo, Psychologist from the University of Caxias do Sul, Specialist in CognitiveBehavioral Therapy, Master Student in Clinical Psychology, Brazil, Email rafaelafaq@msn.com

Received: July 25, 2017| Published: January 09, 2018

and successful strategies. In addition, stimulation activities such as cognitive training and social interactions are reinforced. ${ }^{3}$

For working with the elderly people must always be articulated with an interdisciplinary team. All exchanges among professionals aim to facilitate interventions and care for this population. ${ }^{3,5}$ All work with older people requires patience and dedication. In addition, it is necessary to enjoy and be satisfied professionally, since, as already mentioned, the elderly population experiences different processes and losses, which will influence the psychological treatment.

\section{Acknowledgements}

None.

\section{Conflict of interest}

Authors declare that there are no conflicts of interest.

\section{References}

1. Ribeiro PCCA. Psicologia frente aos desafios do envelhecimento populacional. Revista Interinstitucional de Psicologia, Juiz de fora. 2015;8:269-283.

2. Knapp P, Beck AT. Fundamentos, modelos conceituais, aplicações e pesquisa da terapia cognitiva. Revista brasileira de psiquiatria. 2008;30(II):S54-S64.

3. Freitas ER, Barbosa AJG, Neufeld CB. Terapias cognitivocomportamentais com idosos. Novo Hamburgo: Sinopsys. 2016;2(1):448.

4. Lobo BOM, Marcelo MR, Gabriela S, et al. Terapia cognitivocomportamental em grupo para idosos com sintomas de ansiedade e depressão: resultados preliminares. Psicologia teoria $e$ prática. 2012;14(2):116-125.

5. Batistoni SST. Contribuições da Psicologia do Envelhecimento para as práticas clínicas com idosos. Psicologia em Pesquisa. 2009;3(2):13-22. 